\title{
Randomised controlled trial of general practitioner intervention in patients with excessive alcohol consumption
}

\author{
Paul Wallace, Stephen Cutler, Andrew Haines
}

\begin{abstract}
Objective-To determine effectiveness of advice from general practitioners to heavy drinkers to reduce their excessive alcohol consumption ( $35 \mathrm{U}$ or more a week for men, $21 \mathrm{U}$ or more for women).

Design-Randomised, controlled double blind trial over 12 months with interim assessment at six months.

Setting-Group practices ( $n=47$; list size averag ing 10000) recruited from Medical Research Council's general practice research framework, mostly in rural or small urban settings.

Patients-Patients recruited after questionnaire survey. Of total of $2571(61.2 \%)$ of 4203 patients invited for interview who attended, 909 (35.4\%) stated that in past seven days they had drunk above the limits set for study and had not received advice; they were randomised to control and treatment groups.
\end{abstract}

Interventions-Patients in treatment group were interviewed by general practitioner (who had had a training session) and received advice and information about how to reduce consumption and also given a drinking diary.

End point-Study aimed at detecting a reduction in proportion of men with excessive alcohol consumption of $30 \%$ in treatment group and $20 \%$ in control group (for women $40 \%$ and $20 \%$, respectively) with a power of $90 \%$ at $5 \%$ level of significance. In addition, corroborative measures such as estimation of $\gamma$-glutamyltransferase activity were included.

Measurements and main results-At one year a mean reduction in consumption of alcohol of $\mathbf{1 8 . 2}$ (SE 1.5) $\mathrm{U} /$ week had occurred in treated men compared with a reduction of $8.1(1.6) \mathrm{U} /$ week in controls $(p<0.001)$. The proportion of men with excessive consumption at interview had dropped by $43.7 \%$ in the treatment group compared with $25.5 \%$ in controls $(p<0.001)$. A mean reduction in weekly consumption of $11.5(1.6) \mathrm{U}$ occurred in treated women compared with $6.3(2.0) \mathrm{U}$ in controls $(\mathbf{p}<0.05)$, with proportionate reductions of excessive drinkers in treatment and control groups of $47.7 \%$ and $29.2 \%$ respectively. Reduction in consumption increased significantly with number of general practitioner interventions. At one year the mean value for $\gamma$-glutamyltransferase activity had dropped significantly more in treated men $(-2.4$ $(0.9) I U / 1)$ than in controls $(+1 \cdot 1(1 \cdot 0) I U / 1 ; t=2 \cdot 7$, $\mathbf{p}<\mathbf{0 . 0 1})$. Reduction in $\gamma$-glutamyltransferase activity tended to increase with number of intervention sessions in men. Changes in $\gamma$-glutamyltransferase activity in women and changes in other indicators in both sexes did not differ significantly between treatment and control groups.

Conclusions-If the results of this study were applied to the United Kingdom intervention by general practitioners could each year reduce to moderate levels the alcohol consumption of some 250000 men and $\mathbf{6 7} 500$ women who currently drink to excess. General practitioners and other members of the primary health care team should therefore be encouraged to include counselling about alcohol consumption in their preventive activities.

\section{Introduction}

Alcohol consumption in the United Kingdom has been on the increase since the second world war and is an important cause of morbidity and mortality. ${ }^{12}$ The government's recent white paper contains proposals to increase the focus on prevention by the primary medical services, and alcohol misuse is included as one of its priorities. ${ }^{3}$ Efforts aimed at reducing alcohol consumption in patients with established drinking problems or alcohol dependency have met with limited success. ${ }^{4}$ There is therefore a need to develop and evaluate strategies for prevention. Several such strategies have been proposed, ${ }^{56}$ among them a concerted effort by general practitioners to carry out a programme of patient education about drinking, to be directed particularly at those who are already at risk because of their alcohol consumption. General practitioners are well placed to carry out preventive work because they are consulted by some $70 \%$ of their patients each year and up to $90 \%$ over five years ${ }^{7}$ and patients expect their doctors to be concerned in health promotion. ${ }^{8}$ Advice from general practitioners can bring about a substantial increase in the numbers of patients who give up smoking. ${ }^{9-11} \mathrm{~A}$ brief intervention package on alcohol was therefore devised and a trial designed to evaluate its impact on patients deemed to be at risk because of their excessive drinking.

\section{Patients and methods}

TRIAL DESIGN

The randomised, controlled, double blind trial was designed to assess the impact on patients with excessive alcohol consumption (defined as at least $35 \mathrm{U} /$ week in men and $21 \mathrm{U} /$ week for women ${ }^{12}{ }^{13}$ ) of advice from the general practitioner to reduce their drinking. The duration of the study was 12 months with an interim assessment at six months. The sizes of the effects to be detected were estimated from the results of previous trials on advice to patients to stop smoking ${ }^{9-11}$ and the findings of a pilot study on 55 excessive drinkers carried out by two of us (PW and $\mathrm{AH})^{14}$ and were as follows: men - a reduction in the proportion of patients with excessive alcohol consumption of $30 \%$ in the treatment group and $20 \%$ in the control group; women - a reduction in the proportion of patients with excessive alcohol consumption of $40 \%$ in the treatment group and $20 \%$ in the control group. (A larger difference was specified for women, as heavy drinking is less common among women.) 
Allowing for a loss to follow up of $25 \%$ in each group, we calculated that 1000 men and 300 women would need to be recruited to give the trial $90 \%$ power to detect the above effects at the $5 \%$ level of significance. In order to recruit enough patients and to determine the feasibility of carrying out the intervention in practices in various settings 47 group practices were recruited from the Medical Research Council's general practice research framework. ${ }^{\text {is }}$ Some of the practices, whose list size averaged around 10000 , were situated in cities, including London, Birmingham, and Newcastle upon Tyne, but most were in rural settings or small urban centres distributed between Bideford in south west England and St Andrews in eastern Scotland.

\section{SCREENING}

A self administered health survey questionnaire ${ }^{16}$ including a quantity/frequency scale and the CAGE ("Have you ever thought you should cut down on your drinking?" "Have you ever been annoyed by other people's criticism of your drinking?" "Have you ever felt guilty about your drinking?" "Have you ever had an early morning drink to steady your nerves [an eye opener]?") ${ }^{17}$ questions in a modified form was distributed to patients aged 17-69 registered with the participating practices. In 23 practices the questionnaire was mailed to a sample of 2000 patients selected from the age-sex register by a system of proportional sampling by year of birth. In the other 24 practices questionnaires were handed out over up to seven months to patients attending the surgery. Further details of the distribution have been described elsewhere. ${ }^{15} 18$

All those patients whose questionnaire responses indicated that they drank excessively were invited to a "lifestyle and health survey interview." A further $25 \%$ of those who were not drinking excessively but who indicated concern about their drinking by answering positively to two or more of the CAGE questions or to a question asking whether they thought that they had a drink problem, or to both, were also invited, as was a random sample of $1 \%$ of the remaining women and $2.5 \%$ of the remaining men; this was in order to determine the performance of the questionnaire as a screening instrument. ${ }^{19}$ Interviews carried out in the surgery by a research nurse who had received training with use of a specially prepared videotape included questions relating to smoking, exercise, and overweight as well as drinking. A systematic history of alcohol consumption in the seven days before the interview was obtained. All patients were given brief advice on general health (smoking, exercise, and diet) and offered the booklet Beating Heart Disease, produced by the Health Education Council (now the Health Education Authority). ${ }^{20}$

\section{RECRUITMENT AND RANDOMISATION}

Patients whose stated alcohol consumption in the week before the interview exceeded the limits were invited to take part in the next stage of the study. They were informed that this was designed to examine changes in lifestyle over 12 months and were requested to provide a blood sample for full blood count and biochemical analysis and to return for a similar interview and blood tests at six months and again at one year. Written consent was obtained. Venesection was performed by the nurses. Blood was sent to the Wolfson Laboratories, Birmingham, for biochemical analysis for activities of $\gamma$-glutamyltransferase and aspartate transaminase and to the practices' local hospital laboratories for estimation of mean cell volume; in order to stabilise the specimens the edetic acid containers were stored in water cooled to $4^{\circ} \mathrm{C}$ and sent to the laboratory as soon as possible in a precooled vacuum container.
Randomisation of patients to treatment and control groups was carried out separately for men and women and balanced with respect to those expressing concern about their drinking. In order to avoid interview bias at subsequent assessments research nurses were not informed of the patients' allocation. General practitioners were notified by mail of patients who had been allocated to the treatment group.

\section{INTERVENTION}

Patients in the control group received no advice from their general practitioner about drinking except at their own request or if there was evidence that their alcohol consumption had already resulted in substantially impaired liver function $(\gamma$-glutamyltransferase activity exceeding $150 \mathrm{IU} / \mathrm{l}$ ). Patients randomised to the treatment group were contacted by their general practitioner and asked to attend for a brief interview. All general practitioners received a training session with use of a specially recorded video programme to illustrate the elements of the intervention. After an assessment interview about the pattern and amount of alcohol consumption and evidence of alcohol related problems and dependence (obtained by using the brief Edinburgh alcohol dependence scale ${ }^{21}$ ) patients were shown a histogram based on figures from a national survey of drinking habits to illustrate how their weekly consumption compared with that of the general population. ${ }^{22}$ Advice was given about the potential harmful effects of their current level of alcohol consumption, backed with the information booklet That's the Limit. ${ }^{23}$ Men were advised to drink not more than $18 \mathrm{U} /$ week and women not more than $9 \mathrm{U} /$ week. Where there was evidence of dependence on alcohol general practitioners were encouraged to advise abstinence.

Patients were given a drinking diary, the front cover of which was a facsimile of an EC10 prescription with the words "Cut Down on your Drinking!" The last page contained a guide to the alcohol content (in U) of a range of drinks. An initial follow up appointment one month later was offered to all patients; subsequent appointments at four, seven, and 10 months were at the discretion of the general practitioner. During these sessions the patient's drinking diary was reviewed and feedback given on the results of blood tests indicating evidence of damage due to alcohol.

\section{ASSESSMENT}

The practice research nurse assessed patients in both treatment and control groups at six months and one year. Every effort was made to ensure that nurses carrying out the interviews remained unaware of the group to which patients had been allocated. A copy of the health survey questionnaire was given to the patients to complete before attending a standard interview almost identical with the original lifestyle and health survey interview. Blood was taken for full blood count and biochemical analysis.

\section{ANALYSIS}

Analyses were carried out separately for men and women. Results were analysed both according to the protocol (by using data obtained at the six month and one year assessments and excluding those who did not attend) and on the basis of intention to treat, but only the second of these, which represent the more conservative estimate of the effects of intervention, are presented in this report. For the intention to treat analysis two patients who died during the trial were excluded. For the remaining patients who did not attend for assessment, we assumed that no reduction in consumption (or laboratory or clinical measurements) had occurred. Those patients who failed to provide blood samples at any stage were excluded from the analysis of laboratory studies. 
Changes were calculated on a within subject basis. $\chi^{2}$ Tests were used to test for differences between groups for non-continuously distributed variables and the unpaired $t$ test used for differences between means. For continuously distributed variables with a nonnormal distribution analyses were performed with log transformed data. The $\chi^{2}$ test for linear trend was used to test for trends in the relation between non-continuously distributed variables (for example, alcohol consumption category and number of treatment sessions). A one way analysis of variance was used in the case of continuously distributed variables. Multiple regression analysis was used to test for the relative influence of possible predictor variables on outcome measures.

\section{OUTCOME VARIABLES}

Stated alcohol consumption in the seven days before interview is generally accepted as being the most reliable indicator of consumption, and this was taken as the principal outcome measure. Consumption as assessed by the health survey questionnaire was taken as a secondary outcome measure and changes in the values of laboratory indicators of alcohol consumption analysed in order to provide objective evidence of changes in alcohol consumption.

\section{Results \\ ATTENDANCE}

The results of the questionnaire distribution have been reported. ${ }^{15} 18 \mathrm{~A}$ total of 2830 men $(11 \cdot 1 \%)$ and 1624 women $(4.4 \%)$ were selected on the basis of their responses for interview, but $164(5 \cdot 8 \%)$ of the men and $87(5 \cdot 4 \%)$ women were subsequently found to be seriously ill or to have died or moved away from the practice area. Of the 2666 men who were invited, 1747 were selected because of a weekly consumption of $35 \mathrm{U} /$ week or more and 427 because they had replied positively to two or more CAGE questions or to the question on self assessment of a drinking problem. A total of 1537 women were invited, of whom 875 indicated that they were drinking at least $21 \mathrm{U} /$ week and a further 344 expressed concern about their drinking. Of those invited, $2571(61 \cdot 2 \%)$ attended the initial interview. The attendance rates, which ranged in the 47 practices from $27 \cdot 1 \%$ to $88.9 \%$, were higher

TABLE I-Mean values at entry to trial (SE in parentheses)

\begin{tabular}{|c|c|c|c|c|}
\hline & \multicolumn{2}{|c|}{ Men } & \multicolumn{2}{|c|}{ Women } \\
\hline & $\begin{array}{l}\text { Treatment } \\
\text { group } \\
(\mathrm{n}=319)^{\star}\end{array}$ & $\begin{array}{l}\text { Controls } \\
(\mathrm{n}=322)\end{array}$ & $\begin{array}{l}\text { Treatment } \\
\text { group } \\
(n=131)^{\star}\end{array}$ & $\begin{array}{l}\text { Controls } \\
(n=137)\end{array}$ \\
\hline \multicolumn{5}{|l|}{ Consumption (U/week): } \\
\hline Interview (last week) & $62 \cdot 2(1 \cdot 6)$ & $63 \cdot 7(1.9)$ & $35 \cdot 1(1 \cdot 5)$ & $36 \cdot 8(1 \cdot 7)$ \\
\hline Health survey questionnaire (quantity/frequency) & $49 \cdot 6(1 \cdot 2)$ & $51 \cdot 2(1 \cdot 2)$ & $28 \cdot 6(1 \cdot 3)$ & $29 \cdot 2(1 \cdot 1)$ \\
\hline$\gamma$-glutamyltransferase (IU/l) & $27 \cdot 8(1 \cdot 4)$ & $26.7(1.3)$ & $13 \cdot 7(1 \cdot 4)$ & $12 \cdot 0(1 \cdot 0)$ \\
\hline Mean cell volume $(\mathrm{fl})$ & $91 \cdot 8(0 \cdot 2)$ & $92 \cdot 1(0 \cdot 2)$ & $92 \cdot 1(0 \cdot 2)$ & $91.8(0.5)$ \\
\hline Aspartate transaminase (IU/l) & $30.0(0.9)$ & $29 \cdot 4(1.0)$ & $21 \cdot 5(1 \cdot 0)$ & $22 \cdot 5(1 \cdot 2)$ \\
\hline Age (yeaps) & $41 \cdot 7(0.8)$ & $41.8(0.8)$ & $43.0(1 \cdot 3)$ & $44 \cdot 6(1 \cdot 3)$ \\
\hline Body mass index $\left(\mathrm{kg} / \mathrm{m}^{2}\right)$ & $25 \cdot 4(0 \cdot 2)$ & $25 \cdot 6(0 \cdot 2)$ & $23 \cdot 2(0 \cdot 3)$ & $23.9(0.4)$ \\
\hline Diastolic blood pressure $(\mathrm{mm} \mathrm{Hg})$ & $81 \cdot 4(0.7)$ & $82 \cdot 2(0 \cdot 7)$ & $75 \cdot 2(1 \cdot 0)$ & $75 \cdot 5(1 \cdot 1)$ \\
\hline Systolic blood pressure ( $\mathrm{mm} \mathrm{Hg}$ ) & $137 \cdot 4(1 \cdot 0)$ & $135.5(0.9)$ & $124 \cdot 1(1 \cdot 7)$ & $126 \cdot 0(1 \cdot 8)$ \\
\hline No (\%) expressing concern about drinking & $173(54 \cdot 2)$ & $168(52 \cdot 2)$ & $70(53 \cdot 4)$ & $70(51 \cdot 1)$ \\
\hline
\end{tabular}

^Two participants who died are excluded from subsequent tables.

TABLE II-Patients drinking excessively according to health survey interview

\begin{tabular}{|c|c|c|c|c|c|}
\hline & \multirow{2}{*}{$\begin{array}{c}\text { No } \\
\text { studied }\end{array}$} & \multicolumn{2}{|c|}{ Excessive at 6 months } & \multicolumn{2}{|c|}{ Excessive at 12 months } \\
\hline & & No & $\%$ & No & $\%$ \\
\hline & & & \multirow{3}{*}{$\begin{array}{c}59 \cdot 1 \underset{76.4}{\chi^{2}=}=21.9 ; \mathrm{p}<0.001\end{array}$} & & \multirow{3}{*}{${ }_{74.5}^{56.3} \chi^{2}=23.6 ; p<0.001$} \\
\hline Treatment group & 318 & 188 & & 179 & \\
\hline Controls & 322 & 246 & & 240 & \\
\hline & & & \multirow{3}{*}{${ }^{73 \cdot 7^{2}} \times$} & & \\
\hline Treatment group & 130 & 69 & & 68 & \multirow{2}{*}{${ }_{70.8}^{52.3} \chi^{2}=9.7 ; p<0.05$} \\
\hline Controls & 137 & 101 & & 97 & \\
\hline
\end{tabular}

among women $(n=981 ; 63 \cdot 8 \%)$ than men $(n=1590$; $59.6 \%)\left(\chi^{2}=7 \cdot 19 ; \mathrm{p}<0.001\right)$ and higher among the older patients and those with lower levels of alcohol consumption according to the questionnaire.

Altogether $656(41 \cdot 3 \%)$ men and $273(27 \cdot 8 \%)$ of the women stated that they had drunk the equivalent of at least 35 and $21 \mathrm{U}$ alcohol respectively in the week preceding the interview and agreed to take part in the study. Of these, seven men and one woman had received medical advice about their drinking in the past year, and three men and one woman asked the nurse for help with their drinking. These patients were excluded together with a further six patients who were subsequently found to be suffering from serious illness and two whose $\gamma$-glutamyltransferase activities exceeded $150 \mathrm{IU} / \mathrm{l}$. Of the remaining 909 who entered the trial, 641 were men and 268 women. There were no significant differences at entry between the treatment and control groups in mean alcohol consumption, proportion concerned about their drinking, laboratory indicators of alcohol consumption, age, body mass index (weight $(\mathrm{kg})$ over height $(\mathrm{m})$ squared), or mean values of blood pressure (table I).

\section{Six month and one year assessments}

A man and a woman, both in the treatment group, died during the study and were excluded from the analyses of outcome. At the six month assessment seven of the men and two of the women were found to have moved out of the practice area. Of the remainder, $556(87 \cdot 8 \%)$ men and $229(86 \cdot 4 \%)$ women attended for the interview. One of the practices, which had recruited two patients to the trial, decided to discontinue participation; in the remainder the overall attendance rates ranged from $57 \%$ to $100 \%$. At the one year assessment a further 17 of the men and two more of the women were found to have moved out of the practice area. Of those available for interview, 530 $(86.0 \%)$ men and $218(83.5 \%)$ women attended. Of the patients who were living in the practice area and were physically able to attend, 34 of the men completed the six month assessment but failed to attend at one year, and conversely 19 men attended the one year assessment though they had failed to attend at six months. The corresponding figures for the women were 12 and five respectively. The attendance rates were not significantly affected by the patients' sex, but in the case of the men the older patients and the lighter drinkers attended significantly more frequently $\left(\chi^{2}\right.$ for linear trend $=5.97, p<0.05$; and $\chi^{2}$ for linear trend $=4.46$, $\mathrm{p}<0.05$, respectively). At the one year assessment in the case of the men the attendance rate of those available for interview was slightly higher in the control group $(n=273 ; 89 \cdot 2 \%)$ than in the treatment $\operatorname{group}(\mathrm{n}=257 ; 82.9 \%)\left(\chi^{2}=5 \cdot 11 ; \mathrm{p}<0.05\right)$.

\section{Intervention sessions}

Of men in the treatment group, $265(83.3 \%)$ attended at least one intervention session, $182(57 \cdot 2 \%)$ attended two, $100(31.4 \%)$ attended three, and 59 $(18.6 \%)$ attended four sessions or more. For women the equivalent figures were $121(92 \cdot 3 \%), 85(65 \cdot 4 \%)$, $52(40 \cdot 0 \%)$, and $32(24 \cdot 6 \%)$ respectively.

\section{PRIN:CIPAL FINDINGS}

\section{Changes in stated alcohol consumption}

The largest changes in stated alcohol consumption took place during the first six months of the trial (table II). For men the reduction at six months in the proportion whose previous week's alcohol consumption was in excess of the limits set for the study was $130 / 318(40.9 \%)$ in the treatment group compared with $76 / 322(23.6 \%)$ in the controls $\left(\chi^{2}=21.9 ; p<0.001\right)$. At one year this difference was maintained with 139 $(43 \cdot 7 \%)$ men in the treatment group no longer drinking 


\begin{tabular}{|c|c|c|c|c|c|c|}
\hline & \multirow{2}{*}{$\begin{array}{c}\text { No } \\
\text { studied }\end{array}$} & \multicolumn{3}{|c|}{ Consumption } & \multicolumn{2}{|c|}{ Consumption change } \\
\hline & & Initial & At 6 months & At 12 months & After 6 months & After 12 months \\
\hline \multicolumn{7}{|c|}{ Men } \\
\hline Treatment group & 318 & $62 \cdot 2(1 \cdot 6)$ & $46 \cdot 7(1 \cdot 7)$ & $44.0(1.6)$ & \multirow{2}{*}{$t=3.6 ; \mathrm{p}<0.001$} & \multirow{2}{*}{$t=4 \cdot 7 ; \mathrm{p}<0.001$} \\
\hline Controls & 322 & $63 \cdot 7(1 \cdot 9)$ & $55 \cdot 5(1.9)$ & $55 \cdot 6(1 \cdot 8)$ & & \\
\hline \multicolumn{7}{|c|}{ Women } \\
\hline Treatment group & 130 & $35 \cdot 1(1 \cdot 5)$ & $24 \cdot 8(1 \cdot 6)$ & $23.6(1.5)$ & \multirow{2}{*}{$t=1 \cdot 1 ; \mathrm{NS}$} & \multirow{2}{*}{$t=2.0 ; \mathrm{p}<0.05$} \\
\hline Controls & 137 & $36 \cdot 8(1 \cdot 7)$ & $28 \cdot 8(1 \cdot 3)$ & $30 \cdot 4(2 \cdot 6)$ & & \\
\hline
\end{tabular}

TABLE IV-Influence of number of general practitioner sessions on alcohol consumption and $\gamma$-glutamyltransferase activity

\begin{tabular}{|c|c|c|c|c|c|}
\hline & \multicolumn{5}{|c|}{ General practitioner sessions } \\
\hline & 0 & 1 & 2 & 3 & 4 \\
\hline $\begin{array}{l}\text { No }(\%) \text { with excessive consumption }{ }^{\star} \\
\text { Mean change in } \gamma \text {-glutamyltransferase (IU/l) (SE) } \dagger\end{array}$ & $\begin{array}{c}\text { Men } \\
42 / 53(79 \cdot 2) \\
+0.4(1.9)\end{array}$ & $\begin{array}{l}54 / 83(65 \cdot 1) \\
-2 \cdot 4(2 \cdot 4)\end{array}$ & $\begin{array}{l}42 / 82(51 \cdot 2) \\
+0.5(1 \cdot 1)\end{array}$ & $\begin{array}{l}17 / 41(41 \cdot 5) \\
-5 \cdot 2(2 \cdot 0)\end{array}$ & $\begin{array}{l}24 / 59(40 \cdot 7) \\
-6 \cdot 6(1 \cdot 6)\end{array}$ \\
\hline $\begin{array}{l}\text { No }(\%) \text { with excessive consumption }{ }^{\star} \\
\text { Mean change in } \gamma \text {-glutamyltransferase (IU/I) (SE) }\end{array}$ & $\begin{array}{c}\text { Women } \\
6 / 9(66 \cdot 7) \\
+0 \cdot 1(2 \cdot 2)\end{array}$ & $\begin{array}{l}26 / 36(72 \cdot 2) \\
-0 \cdot 1(0 \cdot 6)\end{array}$ & $\begin{array}{l}18 / 33(54 \cdot 5) \\
-0 \cdot 2(0 \cdot 4)\end{array}$ & $\begin{array}{l}8 / 20(40 \cdot 0) \\
+0 \cdot 8(1 \cdot 7)\end{array}$ & $\begin{array}{l}10 / 32(31 \cdot 3) \\
+0 \cdot 8(1 \cdot 7)\end{array}$ \\
\hline
\end{tabular}

${ }^{\star} \chi^{2}$ test for linear trend: men $50 \cdot 0, \mathrm{p}<0 \cdot 001$; women $23 \cdot 9, \mathrm{p}<0 \cdot 001$.

tOne way analysis of variance: $\mathrm{men}, \mathrm{F}=3.4, \mathrm{p}<0.01$.

in excess of the limits compared with $82(25 \cdot 5 \%)$ of the controls $\left(\chi^{2}=23.6 ; p<0.001\right)$. The equivalent figures for the women at six months were $61(46.9 \%)$ in the treatment group compared with $36(26 \cdot 3 \%)$ in the controls $\left(\chi^{2}=12.3 ; \mathrm{p}<0.001\right)$, and at one year 62 $(47.7 \%)$ in the treatment group compared with 40 $(29.2 \%)$ in the controls $\left(\chi^{2}=9.7 ; p<0.05\right)$.

For men in the treatment group the mean within subject reduction in stated weekly alcohol consumption at six months compared with entry to the trial was $15 \cdot 5(\mathrm{SE}=1 \cdot 5) \mathrm{U}$, which was significantly greater than the reduction of $8.2(1.5) \mathrm{U}$ in those in the control group $(t=3.6 ; \mathrm{p}<0.001)$ (table III). The difference between the groups in the magnitude of reduction of stated alcohol consumption between entry and one year was greater, the mean reduction in the treatment group being $18 \cdot 2(1 \cdot 5) \mathrm{U}$ and in the controls $8 \cdot 1(1 \cdot 6) \mathrm{U}$ $(t=4.7 ; \mathrm{p}<0.001)$. For women there was no significant difference between the two groups in reduction in consumption at the six month stage (treatment group $10.3(1 \cdot 3) \mathrm{U}$, controls $8.0(1 \cdot 6) \mathrm{U} ; t=1 \cdot 1, \mathrm{NS})$, but at the 12 month assessment the difference was significant (treatment group $11.5(1.6) \mathrm{U}$, controls $6.3(2.0) \mathrm{U}$; $t=2 \cdot 0, \mathrm{p}<0.05)$.

For both men and women the proportions with excessive alcohol consumption by our definition at the one year assessment were significantly lower in those who had attended more of the general practitioner intervention sessions (table IV).

The findings of the health survey questionnaire were broadly similar to the interview, except in the case of women assessed 12 months after entry to the trial, in whom there was no significant difference in consumption between the treatment and control groups.

\section{Laboratory studies and clinical findings}

Of the 610 men and 258 women who provided blood

TABLE V-Mean values for $\gamma$-glutamyltransferase activity (SE in parentheses)

$\gamma$-glutamyltransferase (IU/l)

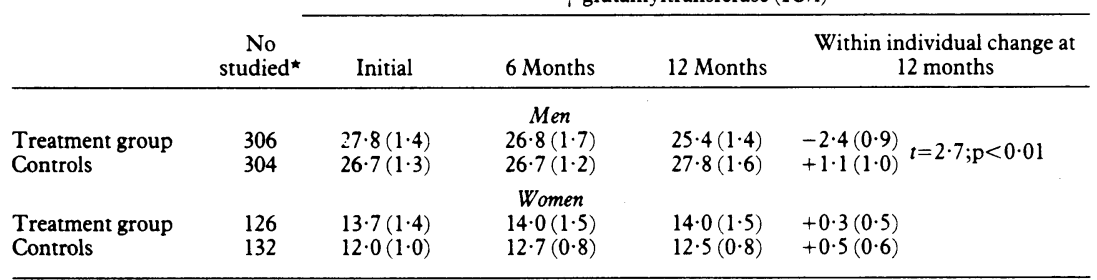

^No blood sample: men 30, women 9 . samples, $172(28 \cdot 2 \%)$ and $32(12 \cdot 4 \%)$ respectively had raised activities of $\gamma$-glutamyltransferase (over $28 \mathrm{IU} / 1$ for men and over $18 \mathrm{IU} / \mathrm{l}$ for women) at entry to the trial. The mean reduction in $\gamma$-glutamyltransferase activity in men over the whole duration of the trial was significantly greater in the treatment group than in the controls, but for women the difference between the treatment and control groups was not significant (table V). Similar results were obtained when the data were log transformed. For men in the treatment group the number of general practitioner intervention sessions was significantly associated with a reduction in mean $\gamma$-glutamyltransferase activity $(\mathrm{F}=3.4 ; \mathrm{p}<0.01)$ (table IV). This relation was not found in women.

There were no significant changes in mean cell volume in either sex over the duration of the trial, nor were there any significant differences between the treatment and control groups. The mean value of aspartate transaminase activity did not change significantly during the trial in either sex, and there were no significant differences between the groups at any stage in either the means or the mean changes. Log transformation of the data did not substantially affect these findings.

A fall in systolic blood pressure of $6.8(0.7) \mathrm{mm} \mathrm{Hg}$ occurred in men in the treatment group, which was significantly $(p<0.05)$ greater than the fall of $4.7(0.7)$ $\mathrm{mm} \mathrm{Hg}$ observed in men in the control group.

\section{Influence of "blindness" on outcome}

At the one year assessment the nurses stated that they had become aware of the allocation to the treatment or control group of $54(21.0 \%)$ of the 257 men in the treatment group and $10(3.7 \%)$ of the 273 in the control group as well as $33(31 \cdot 1 \%)$ of the 106 women in the treatment group and $5(4.5 \%)$ of the 112 in the control group. In most cases this occurred because the patients spontaneously volunteered the information that they had been counselled by their general practitioner. In men the proportion in the treatment group whose consumption at 12 months was excessive was significantly lower among those whose treatment allocation was known by the nurse who conducted the interview $(19 / 54 ; 35 \cdot 2 \%)$ compared with the rest $(106 / 203 ; 52 \cdot 2 \%)\left(\chi^{2}=5 \cdot 3 ; p<0 \cdot 05\right)$. No such difference was seen in women.

\section{Factors influencing outcome}

The proportion of patients with excessive alcohol consumption at the end of the trial was higher 
among those who were heavier smokers at the start (men, $\chi^{2}$ for linear trend $=9.7, \mathrm{p}<0.01$; women, $\left.\chi^{2}=3 \cdot 7, p=0 \cdot 06\right)$. There was no evidence that smoking increased as alcohol consumption fell. Changes in alcohol consumption were not significantly affected by patients' expressions of concern about their drinking at entry to the trial, age, or body mass index. Among the patients in the treatment group for whom evidence of dependence was assessed by using the brief Edinburgh alcohol dependence scale there was no relation between early dependence (score of 2 or more) and outcome.

\section{Lifestyle changes during trial}

Stated cigarette consumption dropped slightly among men and women in both groups during the trial; there was no significant difference in reduction between the patients in the treatment and contro groups. There was no significant change in reported frequency of taking exercise or of dieting to lose weight among either men or women.

\section{Discussion}

Intervention by general practitioners resulted in an appreciable reduction both in quantity of alcohol consumed and in the proportion of patients drinking excessively. After 12 months the net effect of intervention was a reduction of nearly one fifth in the proportion of excessive drinkers of both sexes. As expected, the largest reduction in consumption occurred during the first six months of the trial after the initial intervention by the general practitioner. The response to treatment appeared to be strongly related to the number of times the intervention was repeated. Though this dose-response effect may have been the result of repeated intervention, it may also reflect the greater willingness of patients prepared to reduce their alcohol consumption to return to their general practitioner. The offer of follow up appointments may none the less have an important part to play in maximising the effectiveness of intervention.

Reliance on self reported alcohol consumption as the principal outcome measure is an important methodological problem in studies of this kind. Trials of intervention in smoking suggest that there may be a deception rate of up to $40 \%$ among participants who claim to have stopped smoking, ${ }^{911}$ and there seems little reason to believe that such deception did not also occur in our study. Indeed, it is generally accepted that heavy drinkers' estimates of consumption are unreliable. One solution is to use informants' reports on subjects' consumption as corroborative evidence, but we thought this impracticable and inappropriate in the present context. We therefore used objective markers of consumption-namely, $\gamma$-glutamyltransferase activity, mean cell volume, and aspartate transaminase activity. Unfortunately, these tests have poor discrimination with regard to alcohol consumption, ${ }^{24-26}$ and at the comparatively low levels of consumption of most of the patients in the trial even significant changes in drinking behaviour might not have been accompanied by changes in these markers in many. Yet reduction in stated alcohol consumption in men was paralleled by a reduction in $\gamma$-glutamyltransferase activity, which was related to the number of general practitioner intervention sessions. Similar changes in $\gamma$-glutamyltransferase activity were not seen in women, probably because drinking levels and proportions with raised laboratory values at the outset of the trial were lower.

The somewhat greater fall in systolic blood pressure in men in the treatment group is further evidence that a true reduction in consumption occurred, in view of the known association between blood pressure and alcohol intake. ${ }^{27}$.

The true magnitude of the effect of intervention may have been underestimated because the patients in the control group also reduced their consumption. Some of this reduction is likely to have resulted from regression to the mean, which would also have occurred in the treatment group; further reduction may have been the result of assessment by the nurse at entry, six months, and one year and the impact of the booklet Beating Heart Disease, which has a brief section on alcohol. When "blindness" of the nurses was not maintained (in about a quarter of treated and fewer than one in 20 control patients) there may have been some bias in assessment of alcohol consumption. Alternatively more compliant patients may have been more likely to inform the interviewing nurse that they had received intervention from their general practitioner.

Little information emerged about factors likely to predict a positive response to intervention. Heavy smokers were least likely to cut down on their drinking as a result of advice. Possibly this is not surprising, given the association between heavy smoking and heavy drinking. Patients' concern about drinking, as indicated by response to the health survey questionnaire, appeared to play no part in determining the response to advice. This may mean that advice from the general practitioner is more important in stimulating patients to reach the "understanding phase" than in bringing them to "action." 28 This issue has been addressed in earlier reports. ${ }^{15} 18$

How representative were the patients in the study? The practices taking part, though largely rural or located in small urban centres, were widely distributed in England and Scotland, and the proportion of mailed questionnaires returned was high; the response to opportunistic distribution by hand was more variable but the responses to the questionnaire were similar for the two groups of respondents. The proportions of heavy drinkers were lower than in a study in an inner city practice. ${ }^{16}$ The greatest source of response bias is likely to have occurred during the second stage of the screening when only just over $60 \%$ of patients invited to the lifestyle and health interview actually attended. Younger patients, who as a group have a comparatively high consumption of alcohol, were underrepresented at the interview.

In practice the health survey questionnaire could be used to define a "high risk" group from whom a more detailed drinking history could be taken either by the general practitioner or as part of health promotion activities undertaken by the nurse. Intervention could start immediately, thus avoiding the problem of dropouts, and medical records of patients with excessive consumption could be flagged to facilitate follow up at subsequent attendances. Materials will be needed in order to encourage general practitioners and other members of the primary health care team to undertake this kind of preventive activity. Those developed for use in our trial have been expanded, refined, and incorporated into a package currently being evaluated by the Health Education Authority and Alcohol Concern.

Around 12 million (65\%) men and 15 million (75\%) women consult their general practitioner each year, ${ }^{29}$ and around $14 \%$ and $3 \%$ of them respectively ${ }^{22}$ regularly drink in excess of the limits chosen for our study. Our findings suggest that if all general practitioners were to participate actively in preventive intervention at least $15 \%$ of these patients - that is, around 250000 men and 67500 women-would reduce their consumption to moderate levels. It remains to be seen whether reduction in alcohol consumption after such advice will be maintained. The government has recently stated its intention to increase the focus of the primary health care services in the United Kingdom on the promotion of health and prevention of illness, naming alcohol misuse among its list of priorities. ${ }^{3} \mathrm{Our}$ 
study lends support for this approach and should encourage general practitioners and other members of the primary health care team to include counselling about alcohol consumption in their preventive activities.

We thank all the general practitioners, nurses, and other staff, as well as the patients, at the $\mathbf{4 7}$ group practices for their invaluable help. We are grateful to Dr T W Meade, Dr G Greenberg, and $\mathrm{Mr} \mathrm{K}$ Rennolls for their advice and support in the design and execution of the study and to all the staff of the MRC Epidemiology and Medical Care Unit at Northwick Park Hospital who have been concerned in the administration of the study. We also acknowledge the help given by the Wolfson Laboratories in Birmingham and by the haematology laboratories serving the practices participating in the trial. The study was generously supported by grants from the Alcohol and Education Research Council, the Brewers Society, the Medical Council on Alcoholism, the Medical Research Council, and Merck Sharp and Dohme Ltd.

1 Central Statistical Office. Social trends. No 16. London: HMSO, 1986 2 Royal College of Physicians. A great and growing evil: the medical consequences of alcohol abuse. London: Tavistock, 1987.

3 Department of Health and Social Security. Promoting better health: the government's programme for improving primary health care. London: HMSO, . CM 249.

4 Edwards G, Orford J, Egert S, et al. Alcoholism: a controlled trial of "treatment" and "advice." F Stud Alcohol 1978:38:1004-31.

5 Royal College of General Practitioners. Alcohol-a balanced view. London CGP, 1986. (Reports from general practice, No 24 .

6 Babor TF, Ritson B, Hodgson R. Alcohol related problems in the primary care setting: a review of early intervention strategies. Br $\mathcal{F}$ Addict 1986;81:23-46. Cartwright A, Anderson R. Patients and their doctors, 1977. London: Roya College of General Practitioners, 1979. (Occasional paper No 8.)

8 Wallace $\mathrm{P}$, Haines A. General practitioner and health promotion: what patients think. Br Med f 1984;289:534-6.

9 Russell MAH, Wilson C, Taylor C, Baker CD. Effect of general practitioners' advice against smoking. Br Med f 1979;ii:231-5.

10 Jamrozik K, Vessey M, Fowler G, Wald N, Parker G, Van Vinakis H Controlled trial of three different anti-smoking interventions in general practice. BrMed f 1984;288:1499-1503.
11 Russell MAH, Stapleton JA, Jackson PH, Hajek P, Belcher M. District programme to reduce smoking: effect of clinic supported brief interventio

12 Anderson $\mathrm{P}$, Cremona $\mathrm{A}$, Wallace $\mathrm{P}$. What are safe levels of alcohol consump tion? BrMed F 1984;289:1657-8.

13 Wallace P, Cremona A, Anderson P. Safe limits of drinking: general practitioners' views. Br Med f 1985;290:1875-6.

14 Haines AP, Wallace P. Detection and management of patients with excessive alcohol consumption in general practice. Australian Alcohol/Drug Review 1985;4:251-5.

15 Wallace P, Brennan P, Haines A. Are general practitioners doing enough to promote healthy lifestyle? Br Med f 1987;294:940-2

16 Wallace $\mathrm{P}, \mathrm{Haines}$ AP. Use of a questionnaire in general practice to increase the recognition of patients with excessive alcohol consumption. Br Med $\mathcal{J}$

17 Mayfield D, McLeod G, Hall P. The CAGE questionnaire; validation of a new alcoholism screening instrument. Am f Psychiatry 1974;131:1121-3.

18 Wallace PG, Brennan P, Haines AP. Drinking patterns in general practice patients. F R Coll Gen Pract 1987;37:354-7.

19 Cutler S, Wallace P, Haines AP. Assessing alcohol consumption in genera practice patients-a comparison between questionnaire and interview. Alcohol Alcohol (in press).

20 Health Education Council. Beating heart disease. London: HEC, 1985.

21 Chick J. Alcohol dependence: methodological issues in its measurement; reliability of the criteria. $B r f$ Addict 1983;78:89-95.

22 Wilson P. Drinking in England and Wales: an enquiry on behalf of the Departmen of Health and Social Security. London: HMSO, 1980.

23 Health Education Council. That's the limit. London: HEC, 1985.

24 Shaper AG, Pocock SJ, Ashby D, Walker M, Whitehead TP. Biochemical and haematological responses to alcohol intake. Ann Clin Biochem 1985;22 50-61.

25 Chick J, Kreitman N, Plant M. Mean cell volume and gamma-glutamyltranspeptidase as markers of drinking in working men. Lancet 1981; 1249-51.

26 Papoz L, Warnet JM, Pequignot MD, Eschwege E, Claude J, Schwartz D. Alcohol consumption in a healthy population-relationship to gamma glutamyl transpeptidase activity and mean corpuscular volume. $\mathcal{F} A M A$ $1981 ; 245: 17,1448-51$

27 Haines AP, Booroff A, Goldenberg E, Morgan P, Singh M, Wallace PG. Ethnic comparisons of blood pressure, smoking, obesity and alcoho consumption. Fournal of Human Hypertension 1987;1:39-46.

28 Prochaska JO, Di Clemente CC. The trans-theoretical approach. Illinois: Dow Jones-Irwin, 1984:193.

29 Royal College of General Practitioners, Office of Population Censuses and Surveys, Department of Health and Social Security. Morbidity statistics from general practice 1981-2; third national study. London: HMSO, 1986.

(Accepted 25 May 1988)

\section{Acquired immune deficiency} syndrome

AIISS: The diquired Immunodeficiency Syndrome. An updated review with abstracts of some of the relevan literature. S J Lachman. Pp 96; paperback, free distribution. South Afric Medical News Tribune Pty Limited. 1988. Sponsored by Lennon Limited. ISBN 0-620-12282-X

AIDS: Medicine, Politics, Society. P A B Clarke. Pp 240; $\$ 15.95$ London: Lester Crook Academic Publishing, 1988. ISBN 1-870915-01-1. Understanding AIIDS, J Starkic, $\mathrm{R}$ Dale. Pp 14t; figs; $\$ 6.95$ paperback. London: Consumers" Association Hodder and Stoughton, 1988. ISBN 0-340-41621-1.

\section{Addiction}

Smokmg Amomg Young Adults M Murray, L Jarretl, A V Swan. R Rumun. Pp 192: 118.50 . Alde shot: A
$05467-1$

\section{Alternative medicin}

The Dark. Side of the Brain. H Oldficld. R Coghill. (Pp 264; figs; $\{8.95$ paperback. Shafteshury: Element Books 1988. ISBN 1-85230-025-6.

\section{Biology}

CVtogenetics and Cell (ienetics. Vol +6 "Human Gene Mapping 9." [Ninth International Workshop, Paris, September 1987.] Ed J Frezal, H P Klinger. (P'p 772; $\{88.20$ paperback.) Basel: Karger, 1987. Distributed by John Wiley and Sons. ISBN 3-8055-4795-1.

Cardiology

Electrocardiography: Self-hisessment. E $K$ Chung. Pp $448 ; 553.45$ paper-
Lange, 1988. Distributed by Prentice2168-1.

\section{Clinical chemistry}

Illustrated Texibook of Clinical Chemistry. W J Marshall. (Pp 336; figs; $£ 12$ paperback.) London: Gower Medical Publishing, 1988. ISBN 0-397-44568-7.

Community medicine

Healih Visiting in Practice. C Robertson. Pp 256; 111.95 paperback Edinburgh: Churchill Livingstone. 1988. ISBN 0-443-03278-5

\section{Computers in medicine}

Progress in Clintical Sichere Senes. "Clinical Information Technology a Practical Guide to Personal Comput ing for Healthcare Clinicians and Managers." D Rowley, H Purser. Pr

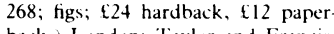
back. London: Taylor and Francis, pard ISBN hardback $0-85$

\section{Diabetes}

Diabetes Cure: a Problem Solving Approach. H Daly, P Clarke, J Field. Ed I Dornan. Pp 216; figs; £12.50 paperback. London: Heinemann, paperback. London: H.
1988. ISBN 0-433-00005-8.

\section{Disasters}

Medicine for Disasters. Ed P Basket, R Weller. Pp 512; figs; f60.) London: Wright, 1988. Distributed by Butterworth. ISBN 0-7236-0949-7

\section{Haematology}

Clmical Management of Bleeding and Thrombosis. E R Burns. (Pp 228; 26.60 Boston: Blackwell Scientific, 1988. ISBN 0-86542-036-X.
Health care issues

Care of the Elderly: Policy and Practice. D J Hunter, N P Mckeganey, I A MacPherson. Pp 196; \&14.50 paperPress 1988 . ISBN 0 -08-036t16-0. Press, 1988. ISBN 0-08-036+16-0.

Medicine and Management. "Health of the Unborn and the Newborn: Aspects" and "Coronary Genetic Aspects" and "Coronary Artery Coronary Angioplasty." [Third Trent Region Seminar on Health Service Developments in the Decade Ahead University Hospital Medical School, Nottingham 24-25 April 1986.] Ed Johnson, M L Jones, P Snell. Pp 84 \$4.25 paperback.) Published privatel for the Trent Regional Health Author ity, 1988. Distributed by the Nuffiel Provincial Hospitals Trust. ISBN 0-9511957-2-7.

Medicine and Management. "Services for Diabetics" and "Screening for Cancer." [Second Trent Region Seminar on Health Service Developments in the Decade Ahead, University of Sheffield, 31 October-1 November 1985. Ed P Snell. Pp 120; figs; $\{4.25$ paperback.) Published privately for the Trent Regional Health Authorit 1988. Distributed by the Nufficl Provincial Hospitals Trust. ISBN 0-9511957-1-9.

Strong Medicine: Health Politics for the Twenty-First Century. S Iliffe. (Pp 160; $\$ 5.95$ paperback.) London: Lawrence and Wishart, 1988. ISBN 0-85315-694-8.

\section{Medical education}

MC.Os: Ophthulmology. N R Galloway, S A Vernon. Pp 120: $\{7.95$ paperback.) London: Springer, 1988. ISBN 3-540-19516-5

Notes for the MRC(FP. K T Palme Pp 240; $\{12.50$ paperback.) Oxfor Blackwell Scientific, 1988. ISBN 0-632-01968-9.
Medical ethics

Comtemporan Issues in Fetal and Neomul Modicine Vol 3 "Ethical Issues at the Outset of Life." Ed W B Weil, $\mathrm{Jr}, \mathrm{M}$ Benjamin. Series editors N N

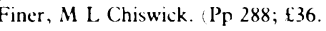
Buston: Blackwell Scientific, 1987 ISBN 0-86542-046-7

\section{Paediatrics}

Infant Feeding: Anatomy of a Con trocersy 1973-1984. Ed J Dobbing. Pp 192; \&16.50.) London: Springer. 1988. ISBN 3-540-19514-9.

Solving Common Pediatric Problems: an Algorithm Approach. C Z Margolis. Pp 224; figs; \$29.95. New York Solomon Press, 1988. ISBN 0-934623. $26-0$

\section{Pharmacology}

The Acetvlator Genes and Drug Response. W W Weber. (Pp 272; figs; 138. New York: Oxford University Press, 1987. ISBN 0-19-503932-7.

Toxicology

Neuropsychological Toxicologv: Identification and Assessment of Human Neurowic Syndromes. D E Hartman. (Pp 336; figs; 224.75 .) New York: Pergamon, 1988. ISBN 0-08-034944-7.

\section{Miscellaneous}

Any Room at the Top?: a Study of Doctors and Their Careers. A summary of the findings of the report "Doctors and Their Careers." I Allen. (Pp 114 £4.95 paperback.) London: Policy Studies Institute, 1988. ISBN 0-85374438-6.

The A-Z of Women's Health C Ammer. (Pp 336; £6.99 paperback.) Wellingborough: Grapevine, 1988. ISBN 07225-1611-8.

Caring at Home. N Kohner. (Pp 132; figs; $\mathfrak{£ 2 . 5 0}$ paperback, discounts for

bulk orders. Cheques payable to King Edward Hospital Fund for London. Cambridge: National Extension Sales, King's Fund Centre 126 Albert Street, London NWI $7 \mathrm{NF}$. ISBN 1 85356-004-9.

Caring Together: Guidelines for Carers' Self-Help and Support Groups. J Wilson. (Pp 72; $\{3.95$ paperback discounts for bulk orders. Cheques payable to King Edward Hospita Fund for London.) Cambridge: N ional Extension College, 1988. Available for Book Sales, King's Fund Centre, 126 Albert Street, Londo NW1 7NF. ISBN 1-85356-005-7. 